\title{
Concerning the relationship between noise on board ship and the onset of hypertension
}

Received: 02 January, 2021

Accepted: 06 January, 2021

Published: 07 January, 2021

*Corresponding author: Dominique Jégaden, Centre for Professional and Environmental Pathologies, Morvan Teaching Hospital (CHRU), Brest, France, E-mail: dominique.jegaden@wanadoo.fr

https://www.peertechz.com

Check for updates

\section{in seafarers}

\section{Dominique Jégaden*}

Centre for Professional and Environmental Pathologies, Morvan Teaching Hospital (CHRU), Brest, France

Establishing a causal relationship between noise level and the onset of high blood pressure is a controversial topic which has been debated for over forty years. This question may seem to some to be secondary, even insignificant, but the considerable number of studies on this issue confirm that is a public health problem that should not be overlooked. Indeed, noise is a ubiquitous nuisance and arterial hypertension a disease that endangers peoples' lives.

In August 2020 a German team [1] (Bolm-Audorff et Al.) published a new meta-analysis on this subject in the International Journal of Environmental Research and Public Health ("Occupational noise and hypertension risk: A systematic review and metaanalysis"). The team selected 180 eligible works from 4,583 papers collected from large databases, ultimately including only 23 in the meta-analysis. To my surprise, one of the 23 articles selected is one that I published in French in 1986, in Archives des maladies Professionnelles [2]. This work involved 455 merchant seamen aged 40 to 55.164 were engine room personnel and 291 were deck crew. The difference in noise exposure level between these two categories of seafarers was evidenced by the existence of a notch at $4000 \mathrm{~Hz}$, typical of damage due to noise above $85 \mathrm{~dB}(\mathrm{~A})$ in engine room personnel, while this notch was not found among the deck crew [3]. The hypertensive sailors included in the survey were those who had permanent levels of systolic blood pressure (SBP) greater than $140 \mathrm{mmHg}$ and of Diastolic Blood Pressure (DBP) greater than $90 \mathrm{mmHg}$, or who were taking antihypertensive medication issued by their attending physician. All blood pressure measurements were taken by the same doctor, using a mercury tensiometer. We calculated a prevalence of $18.90 \%(12.8-25 \%)$ of confirmed hypertension among engine room personnel against $11.68 \%(7.9215 .44 \%)$ among deck crew $(\mathrm{p}<0.05)$. The calculated relative risk was 1.62 (1.03-2.53). No relationship was found between the extent of hearing loss and the existence of hypertension. This risk was independent of other causes of hypertension (obesity, alcoholism, family history). Our paper also indicated that the occurrence of hypertension was linked, on the one hand, to a high level of noise (>85 dB (A)) and, on the other hand, to a long duration of exposure to noise, greater than 20 years. The conclusions of the Bolm-Audorff meta-analysis (1) provide clear evidence for the relationship between exposure to industrial noise above $85 \mathrm{~dB}(\mathrm{~A})$ and the risk of arterial hypertension. This relative risk is calculated at 1.72 (1.48-2.01). Although some studies [4] do not demonstrate this relationship, including in the maritime environment [5] (that is the reason why it is always a hypothesis), several other recent metaanalyses [6-9] also conclude that there is a positive relationship between noise and hypertension. $\mathrm{Fu}$, et al. [6] found a relative risk at $1.62(1.40-1.88)$ and Skogstad [7] at 1.68 (1.10-2.57), equivalent to that which we had calculated. The mechanism mentioned by Maschke [10]. is a vasoconstriction effect caused by a central action due to noise, causing an increase in peripheral resistance, as well as an increase in the release of stress hormones (adrenaline, norepinephrine and cortisol).

The resumption of our work, dating back almost 40 years, in this very recent metaanalysis, inspires us a few thoughts:

1. The maritime environment constitutes a model, an in vivo laboratory, making it possible to study the reactions of human beings to physical constraints such as noise and vibration, but also psychological (stress, 
confinement, isolation, boredom), or again, as we have seen recently with the Covid 19 pandemic, spread of infection in confined living and working environments.

2. Over the past 40 years there has been significant technological progress concerning the reduction of noise levels on board ship (improved insulation of living areas, automation of engines, soundproofed surveillance rooms, diesel-electric propulsion...) and engine room personnel are subjected to less noise that might cause damage to their health such as deafness or, as regards this letter, hypertension. Tu and Jepsen [11] report it all the same ("Measured noise levels are highest in the engine rooms, followed by the levels on deck. This may partly explain the high prevalence of hypertension for seafarers working in these two areas."). On the other hand, Oldenburg [12] does not include noise as the cause of hypertension in sailors. However, the same author has recently shown that engine room personnel remain exposed to harmful noise levels, greater than $85 \mathrm{~dB}(\mathrm{~A})$ [13].

3. We must also maintain strict medical surveillance among fishermen, many of whose vessels are still very noisy, and should not forget that noise is added to many other risks of hypertension, such as obesity, a sedentary lifestyle and alcoholism.

\section{References}

1. Bolm-Audorff U, Hegewald J, Pretzsch A, Freiberg A, Nienhaus A, et al. (2020) Occupational noise and hypertension risk : A systematic review and metaanalysis. Int J Environ Res Public Health 17: 6281. Link: http://bit.ly/2KXz45L

2. Jégaden D, Le Fluart C, Marie Y, Piquemal B (1986) Contribution to the study noisehigh blood pressure. Concerning 455 merchant sailors aged 40-55 years. (Contribution à l'étude de la relation bruit-hypertension artérielle. À propos de 455 marins de commerce âgés de 40 à 55 ans). Arch Mal Prof 47: 15-20.
3. Jégaden D (1984) Noise on board ships : its impact on the hearing function of merchant seamen (Bruit à bord des navires : son retentissement sur la fonction auditive des marins de commerce). Arch Mal Prof 45: 345-349. Link:

4. Tessier-Sherman B, Galusha D, Cantley LF, Cullen MR (2017) Occupational noise exposure and risk of hypertension in an industrial workforce. Am J Ind Med 60: 1031-1038. Link: https://bit.ly/2XcksI9

5. Nguyen TPN, Le DD, Nguyen MDM, Nguyen AHP, Ha B, et al. (2020) Noise Exposure and its relationship with Hypertension among Fishermen in Thua Thien Hue Province, Vietnam. Journal of Integrated Community Health 9: 316. Link: http://bit.ly/2Xckyt1

6. Fu W, Wang C, Zou I, Liu Q, Gan Y, et al. (2017) Association between exposure to noise and risk of hypertension : a meta-analysis of observational epidemiological studies. J Hypertens 35: 2358-2366. Link: http://bit.ly/38i5oZV

7. Skogstad M, Johannessen HA, Tynes T, Mehlum I, Nordby K, et al. (2016) Systematic review of the cardiovascular effects of occupational noise. Occup Med 66: 10-16. Link: http://bit.ly/2JLYbaO

8. Yang Y, Zhang E, Zhang J, Chen S, Yu G, et al. (2018) Relationship between occupational noise exposure and the risk factors of cardiovascular disease in China. A metaanalysis. Medicine 97: e11720. Link: http://bit.ly/3pU8xVK

9. Pyko A, Lind T, Mitkovskaya N, Ogren M, Östenson CG, et al. (2018) Transportation noise and incidence of hypertension. Int $\mathrm{J}$ Hyg Environ Health 221: 1133-1141. Link: http://bit.ly/397cCyS

10. Maschke C, Hecht K (2007) Mechanisms controlling the interaction between noise and particules. Proceedings of the International Workshop on Combined Environmantal Exposure: Noise, Air Polluants and Chemicals. Joint Research Centre of the European Commission, Ispra (Italy). Link: https://bit.ly/38kxeV7

11. Tu M, Jepsen JR (2016) Hypertension among Danish seafarers. Int Marit Health 67: 196-204. Link: http://bit.ly/3onjbnp

12. Oldenburg M (2014) Risk of cardiovascular diseases in seafarers. Int Marit Health 65: 53-57. Link: http://bit.ly/3bj6Q01

13. Oldenburg M, Felten C, Hedtmann J, Jensen HJ (2020) Physical influences on seafarers are different during their voyage episodes of port stay, river passage and sea passage : A maritime field study. Plos One 15: e0231309. Link: http://bit.ly/2XckVUr
Discover a bigger Impact and Visibility of your article publication with

\section{Peertechz Publications}

Highlights

* Signatory publisher of ORCID

* Signatory Publisher of DORA (San Francisco Declaration on Research Assessment)

* Articles archived in worlds' renowned service providers such as Portico, CNKI, AGRIS, TDNet, Base (Bielefeld University Library), CrossRef, Scilit, J-Gate etc.

* Journals indexed in ICMJE, SHERPA/ROMEO, Google Scholar etc.

* OAI-PMH (Open Archives Initiative Protocol for Metadata Harvesting)

* Dedicated Editorial Board for every journal

* Accurate and rapid peer-review process

* Increased citations of published articles through promotions

* Reduced timeline for article publication

Submit your articles and experience a new surge in publication services (https://www.peertechz.com/submission).

Copyright: @ 2021 Jégaden D. This is an open-access article distributed under the terms of the Creative Commons Attribution License, which permits unrestricted use, distribution, and reproduction in any medium, provided the original author and source are credited. 